\title{
Transnational Journalism History and China Matters
}

\begin{abstract}
As a valuable historiographical approach to investigating media and culture in the Asia-Pacific region, transnational journalism history has begun to inquire into the interconnectedness between media landscapes of Western countries and those of the Far East. This article reflects on the historical interconnectedness between Chinese journalism and its overseas counterparts, showing how China matters appeal to the growing discourse of transnational journalism history. It begins with a concise review of the rise of transnational history and its influence on media historiography. Turning focus to the Chinese context, the article explores the entanglements between Chinese journalism history and the discourse of transnational journalism history. It provides examples of media agents, networks, concepts and norms, journalistic content, and journalism education involved in the transnational projects between China and other countries. In doing so, this article envisions possible directions for future research.
\end{abstract}

\section{Keywords}

media history, journalism, transnationalism, Chinese studies, networks

\section{Introduction}

In the academic terrain of journalism and media history, the call for a transnational approach has become a trend in recent years. Different expressions such as 'transnational media history', 'transnational television history', 'entangled media histories', and 'transnational journalism history', amongst others, were adopted to denote a similar idea. ${ }^{1}$ This thriving initiative that de-emphasises the territorial borders of nation-states has been echoed in a growing body of research from scholars across continents. Research clusters and on-going collaborative projects include, but are not limited to, the European 
Television History Network, Transnational Radio Encounters, and the research network of Entangled Media Histories. There are also research institutes dedicated to fostering and conducting research on the history of transnational media flows. In addition, numerous international conferences and workshops focusing on the topic of transnational journalism history have been held by universities in Hamburg, Sydney, Augusta, London, Loughborough, Lund, Shanghai, and many other places. The American Journalism Historians Association also grants the Jean Palmegiano Award each year for an outstanding research paper relating to transnational aspects and issues of journalism history. Transnational journalism history is thus on course to becoming an established research strand.

Transnational journalism history has become a valuable historiographical approach to investigating media and culture in the Asia-Pacific region. ${ }^{2}$ In recent years, scholars have also begun to call for inquiries into the transnational interconnectedness between media landscapes of Western countries and those of the Far East. ${ }^{3}$ However, with the growing appeal of including Asian matters in the global engagement of transnational journalism history, the voice and presence of China-based scholars is still somewhat faint, and one central question remains unclear to Western media historians: What role can the historical development of China in general and Chinese journalism in particular play in the writing of a transnational journalism history?

By illustrating and reflecting on the historical interconnectedness and entanglements between Chinese journalism and its overseas counterparts, this article shows that Chinese journalism history - and, more broadly, the development and international position of China as an influential country within Asia - could be integrated into the discourse of transnational journalism history. It begins with a concise review of the rise of transnational history and its influence on journalism and media historiography. Drawing on secondary literature, it points out that the transnational flows of individuals, networks, journalistic content and education could be utilised in approaching transnational journalism history, as they allow scholars to understand the interconnectedness and entanglements between Chinese journalism and its Western 'others'. Mainly relying on primary sources, the article then continues to explicate the historical interconnectedness between Chinese journalism and its foreign counterparts. It particularly focuses on the transnational flows of individuals, organisations, networks, journalistic content and journalism education involved in diverse transnational projects. In doing so, this article contributes to the scholarship of transnational journalism history by bringing China matters to the doorstep of Western academia and envisioning possible directions for future research. 


\section{Theorising transnational journalism history}

Transnational history was a product of the 'cultural turn' and the 'transnational turn' in the research area of international history in the 1980s and 1990s. Its forerunners and advocates argued that researchers of international history had been fettered by their national frames of reference. Since the nation-state had been employed as the central unit of analysis, scholars tended to narrate and interpret international history by focusing on the social, economic, and political structures of one specific nation-state. Despite scholars having found interactions between nation-states, they tended to analyse these interactions from a perspective of nation-centrism, with international history becoming a 'nation-centred understanding of modern history'. ${ }^{4}$

The transnational turn of international history shifts the focal point of scholars from being restricted to a single country towards exploring the interconnectedness between countries. This approach asks scholars to investigate a certain historical phenomenon across national boundaries rather than examining all historical phenomena within one country. The elements of cultural context may include customary behaviours, modes of cognition, values, ideologies, and emotions. The cultural and transnational analysis of international history leads scholars to focus on the transference, exchange, and collision of cultural issues across territorial borders. As a consequence, transnational history de-emphasises the nation-state as the analytical unit and seeks to understand international relations by examining the transnational flows of social agents, products, values, institutions, and ideas.

It should also be noted that, in contemporary scholarship, transnational history has been regarded as both a perspective and a research paradigm. The works of historians such as Ian Tyrrell, Thomas Bender, and Niall Whelehan tend to treat transnational history as a perspective (or an approach) to understanding national history. They do not deny the value of the nation-state, but see the transnational approach as useful for examining national history in the spectrum of transcultural issues and globalisation. ${ }^{5}$ Conversely, Harvard historian Akira Iriye suggests that historical issues be understood by examining their global structure, since it was the global context, not the nation-state, that primarily shaped historical phenomena such as religions and identities. ${ }^{6}$ For him, transnational history is more than a perspective; it is a paradigm of historical research, or a master narrative. Transnational history particularly uncovers 'the whole of humanity' in the process of globalisation through a close examination of multinational enterprises, non-governmental organisations, and 
religious establishments. In this fashion, transnational history becomes the history of globalisation. Despite these diverse understandings of transnational history, Pierre-Yves Saunier has tried to reconcile the views of Tyrrell (and his cohort) and Iriye by proposing three basic tasks of transnational history. The first is to historicise interconnectedness between communities, polities, and societies regardless of territories. The second is to evaluate the influence of foreign factors on domestic issues, and the impact of the domestic features on the perception of foreign affairs. The third task, he argues, is for transnational history to interrogate the flows of trends, patterns, organisations, individuals, and ideas in a globalised space. ${ }^{7}$

Transnational journalism history is a reflection of the transnational turn within the research area of journalism and media studies. This reflection initially emerged in European countries and first challenged the Anglo-American narrative of journalism history. As Marcel Broersma points out, the traditional 'grand narrative of journalism history' is rooted in Anglo-American journalism and scholarship, which is 'predetermined by predominantly Anglo-American notions' 8 This scholarship, stressing a linear progression of the journalistic industry and democratic ideas, treats the history of journalism as a progressive development from partisan newspaper industries to professionalism. However, as Broersma argues, this approach 'diminishes the existence and influence of other journalistic styles not centred on news facts and objectivity but on literature, reflection and opinion, which have long been very much alive in European history'. 9

In many European countries, the approach of transnational history is derived from entangled history (histoire croisée), which is a research tradition within European scholarship resulting from the intertwined connections between European countries dating back to the medieval age. ${ }^{10}$ Marie Cronqvist and Christoph Hilgert define entanglement as 'intended or unintended, obvious or hidden, structured or chaotic interrelations in space, knowledge or time'. ${ }^{11}$ Historical entanglement is 'the manner in which an "object" of historical study (for example, a concept, discourse, or identity) is constituted at the meeting point or intercrossing among various historical contexts, as opposed to its being considered in only one isolated discursive context'. ${ }^{12}$ Entangled history, therefore, concentrates on multicultural, trans-discursive, and diachronic entanglements. Contemporary development of institutions such as the European Union and of communication technologies amplifies the importance of researching such entanglements across borders. As many media historians have observed, before the 1980s a few national media organisations (newspapers, radio networks, and TV stations) monopolised the channel of information and dominated the media 
landscape in a single country. Because of this, scholars tended to focus on programmes, content, genres, institutions, and regulations of these national media conglomerates within a single national context, and considered the function of national media as maintaining the culture and national identity of this imagined community. ${ }^{13}$

However, the development of the internet and other digital technologies has increased the extent and pace of globalisation, causing some media historians to see media as a cultural agent of modernisation and to call for de-emphasising of national boundaries in research. ${ }^{14}$ Responding to this appeal, transnational journalism history studies the transnational interactions of media landscapes and the flows of media agents, audiences, ideas, genres, norms, content, institutions, policies, technologies, and formal or informal networks across borders. Key individuals, texts, and organisations related to this transnational process are taken into special account. It is, of course, impossible and unnecessary to entirely ignore nation-states and national borders, and thus transnational and transcultural incorporation, appropriation, and adaption of alien ideas, technologies, and norms into the local context are also a concern of transnational journalism history. ${ }^{15}$

\section{Transnational agents and networks}

The interactions between China and European countries date back to ancient times, exemplified by the Silk Road trading route. However, if we follow German historian Sebastian Conrad's perspective, who sees cross-border mobility of social agents, transnational diffusion of technologies, and transference of knowledge across national borders as the three key aspects of transnational history, ${ }^{16}$ entanglement between China and the West on a large scale only became possible from the nineteenth century onwards. Despite international trade and Catholic missions bringing Western material culture to China prior to the eighteenth century, the imperial government severely restricted the frequency of these interactions from the eighteenth century onward. In the nineteenth century, due to its successive military failures against Western countries, China was forced to become involved in processes of globalisation. As a consequence, Western concepts, products, individuals, institutions, and technologies flowed into China, and the influx of Chinese migrants to the United States, British colonies, Japan, and Australia became conspicuous from that point onward. ${ }^{17}$ 
Transnational agents are fundamental to the interconnectedness between Chinese journalism and its overseas 'others'. It refers to the individuals, organisations, and networks involved in transnational media and journalism history. They travel across territorial and cultural contexts with their own economic, socio-political, and cultural capital. They mediate cultures, transmitting information between their home countries and the destination countries. Through interacting with local people of their destinations, they transform others and are, in turn, transformed themselves, resulting in their complex and 'liquid' identities. In this sense, they are not only social agents who enabled cultural hybridity but also themselves the products of transnationalism. ${ }^{18}$ Moreover, in many cases, transnational individuals, organisations, and networks are not independent of each other; they rely on each other to different degrees. In this light, tracing the flows of transnational individuals together with related organisations and concerned networks would be meaningful, as it would enable researchers to probe into the complexity of transnational entanglements. In the following paragraphs I will examine relevant examples of transnational agents and networks.

Western Protestant missionaries were amongst the early generation of transnational agents involved in modern Chinese journalism history. The missionaries imported Western-style metallic typographic printing technologies into China, establishing modern printing houses and publishing Western-style secular periodicals to disseminate Western knowledge in coastal cities of China, such as Guangzhou (Canton), Fuzhou (Foochow), and Shanghai, thus marking the inauguration of the modern Chinese publishing industry. ${ }^{19}$ From a perspective of nation-centrism, the importation of Western technology and the circulation of Western concepts via missionaries was closely associated with Western military aggression in China, and therefore could be seen as a by-product, if not an arm, of Western colonialism and cultural imperialism. ${ }^{20}$ Framed by this lens, the history of missionary publishing enterprises in China is treated by media historians as either implementing Western colonial power or bringing political and cultural modernity to a collapsing empire. Both narratives stress Western power being exerted on the media landscape of China. The approach of transnational journalism history adds an additional dimension, holding that the missionaries' publishing enterprises in China were part of an evangelical globalising project based on its own agenda. In this light, the transplanted technologies, knowledge, organisations, publications, and missionaries themselves were the transnational agents that enabled this globalising project.

Before their arrival in China, European Protestant missionaries had already set up printing enterprises and published religious literature at a few European colonies in Asia, ${ }^{21}$ which made their 
expansions towards imperial China and Japan (both independent sovereign nations at the time) an inevitable next step. In other words, the missionaries' publishing enterprise in China was just a node on the system of their global publishing network. As a part of this missionary information network, the China node acted to serve Chinese-speaking communities, including a wide readership in Malacca, Singapore, Batavia, Penang, and Siam (rather than just China alone). The readerships also included people in Japan, since Japanese literary language had made wide use of Chinese characters and vocabulary at the time. ${ }^{22}$ Because of this, the nineteenth-century missionary magazine Liuhe Congtan (Shanghai Serial), which was published in China, could be circulated in Meiji Japan, and the main reading market of the missionaries' Cha Shisu Meiyue Tongji Zhuan (Chinese Monthly Magazine) was actually spread throughout Southeast Asia.

For European missionaries creating their global publishing network, China's conservative policies against foreign missions was a less significant issue than the difficulty of learning the Chinese language and culture. In 1805, the Chinese emperor issued an ordinance forbidding Western missions, decreeing that those who broke the law could face execution. This harsh law certainly made the physical survival of missionaries a grave challenge. Yet, this restriction never impeded Western missionaries. Only two years after the release of the ordinance, the Anglo-Scottish missionary Robert Morrison landed in Guangzhou, marking the beginning of the Western Protestant mission in China. Though preaching the Christian Gospel was illegal in China at the time, another 60 Western missionaries followed in Morrison's footsteps. In 1833, the Prussian missionary Karl Gutzlaff established the first modern Chinese-language newspaper in Guangzhou. Before that, the missionaries had spent close to three decades seeking to grasp the Chinese language and optimising their printing technology in an effort to publish in it.

Once we see the missionary publishing enterprise as part of a globalising project, we find the transnational flow of capital relating to it to be a more complicated phenomenon than what classical colonialism theory could reveal. The missionaries' transnational enterprise was intertwined with the trend of economic globalisation. For instance, to maintain the business of his Chinese-language periodical Dongxiyang Kao Meiyue Tongji Zhuan (Eastern Western Monthly Magazine), Gutzlaff went into partnership with the Scottish opium dealer William Jardine. In the heyday of the global opium trade, Jardine and his company financially sponsored the periodical, and Gutzlaff reciprocated by providing him with intelligence on China. The East India Company also shared the Chinese opium market and thus required capable 'China hands'; the representatives of its Guangzhou branch - John 
Roberts, Henry Browne, and John Elphinstone - thus helped Morrison set up his publishing house in Macau and supported him in his request for advanced printing technology so that the world's first Chinese-English dictionary could be printed and circulated.

There were a number of formal and informal networks for missionaries of different national and denominational backgrounds, which significantly enhanced their transnational enterprise. Before the 1870s, all of the six publishing houses in Shanghai were operated by Western missionaries associated with different denominations - for example, the Congregational Church ran the London Missionary Society Press from 1843, the Missionary Society of the Methodist Episcopal Church opened the Methodist Publishing House (Hua Mei Shu Guan) in 1854, and the Presbyterian Church established the American Presbyterian Mission Press (Mei Hua Shu Guan) in 1860. These publishing houses served as physical spaces for missionaries from the same denomination (and sometimes from associated denominations) to interact with each other. In her introduction to The Chinese Recorder Index, Kathleen Lodwick points out that the missionaries 'wanted to spread the knowledge of Western Christianity and technology to the Chinese, but also they wished to exchange information among themselves about the work they were doing'. ${ }^{23}$ The missionaries therefore established 'fellow' magazines to create an informal network, uniting the bulk of missionaries regardless of their diverse national and denominational backgrounds. Taking The Chinese Recorder as an example, this Shanghai-based English magazine welcomed submissions from all missionaries in China and South Asia. Its editors were from different denominations, including the American Methodist Episcopal Mission, American Presbyterian Mission, London Missionary Society, and American Southern Baptist Mission, amongst others. However, despite their extent and activity, these transnational networks have received little scholarly attention.

The missionary networks included Chinese nationals as well. Since imperial China restricted formal interactions between missionaries and local people, only authorised officials were allowed to engage with Western businessmen and missionaries. Driven by commercial interests, there were also many local Chinese who were courageous enough to join the missionary publishing enterprises and acted as mediators between Western and Chinese cultures. These China-born intermediaries became transnational agents flowing across territorial boundaries. Assimilating Western concepts, printing technology, and editing skills, many of them later became publishers, editors, or journalists for media organisations both inside and outside China. 
Another pertinent group of transnational agents were foreign journalists and correspondents in China, who have drawn scholarly attention for a few decades. ${ }^{24}$ During the late imperial period, since Western audiences had little interest in reading news about China, only a couple of international news agencies, such as Reuters and the Associated Press, appointed and allocated China correspondents. Yet, with the outbreak of the Chinese Revolution in 1911, and particularly during the Second World War, an increasing number of Western journalists and freelancers began to report from China. From the nation-centric perspective, these transnational individuals were old China hands who acted as both international mediators between governments and transmitters of information. They had been involved in the domestic affairs of both China and their home countries, and also exerted influence on international relations. ${ }^{25}$ Documenting biographies and anecdotes of these journalists and scrutinising their involvement in the history of international relations is certainly of importance. Yet, from the perspective of transnational journalism history, which regards Western news workers in China as transnational agents, additional research questions and intriguing aspects deserve further examination.

Similar to missionaries, foreign correspondents are always associated with each other through formal or informal networks. The 'Hankow Gang', as historians named it, was a typical example. ${ }^{26}$ This group of Western journalists and freelancers residing and reporting in Hankow (Hankou) during the early years of the Second World War did not constitute a formal organisation, but its 'members' knew each other well and regularly held dinner parties and shared sources of information. In addition, they often visited the frontlines together and did joint interviews with Chinese soldiers and wounded civilians. The Hankow Gang, in the classic and Anglo-American narrative, includes big names in journalism history such as Theodore White, Edgar Snow, Tillman Durdin, Anna Louise Strong, Freda Utley, and Agnes Smedley. Many of them were Missouri graduates and pro-Communist professional reporters who had experienced the Spanish Civil War. ${ }^{27}$

However, the autobiography of New Zealand freelancer Robin Hyde (Iris Wilkinson) presented a picture of an alternative - and more informal and loosely organised - Hankow Gang. This group included names less noted in the American narrative of journalism history, such as W. H. Auden and his partner, Christopher Isherwood. Many of them, like Hyde herself, were adventuring writers and entered the realm of China reporting by coincidence. Compared with the Missouri graduates, this other group of transnational journalists maintained a looser connection with the Chinese government, as many of their names were not even registered with the Chinese Department of 
Publicity. Their connections were not restricted to Hankow, as they expanded to Shanghai and Xuzhou. Within their network, many members shared more romantic interests such as writing poetry, but internal conflicts also existed in a conspicuous fashion. ${ }^{28}$

The narrative of an alternative Hankow Gang leads to some more important questions. How did different networks of China's foreign journalists interact with and exert an impact on each other? Was there a hierarchy between networks, or within the same network? Was the privilege and right of interviewing and publishing equally shared within one network? How did power transmit between networks? Did the above affect transnational news production? The answers to these questions remain unclear. Moreover, even though archives show that many broadcast journalists, such as Harry Fannery and Roy Porter of CBS, and Carl George of WGAR (Cleveland), had been assigned to report in China, little light has been cast on the transnational flows of broadcast and photographic journalists. $^{29}$

Robin Hyde and her alternative narrative of the Hankow Gang also lead to the question of the 'liquid' transnational identities of foreign journalists in China. This entails two related considerations. The first is the living conditions of foreign journalists. From the late imperial period, compared with their Chinese counterparts and their fellow journalists working in Western countries, foreign journalists in China held a higher social status and maintained close connections with high-ranking Chinese officials, rendering them a relatively powerful group of people. Their extensive privileges were not limited to the aspect of reporting. In the 1940s, despite the war raging on, the Chinese government spent 490,000 US dollars per month on hosting foreign journalists, and from 1947 this number continued to rise. The Chinese government even established press hostels for foreign journalists in the wartime capital Chongqing. During wartime, foreign journalists continued enjoying parties and importing goods such as fine French wine. From 1943, despite very strict meat rationing in Chongqing, foreign journalists were free to enjoy as much pork and beef as they liked. ${ }^{30}$

Another aspect that should be considered is the entangled life trajectories between Western journalists and local Chinese people. Robin Hyde was a typical example. She had been a feminist journalist for various New Zealand periodicals before she set off on her adventure to the British colony of Hong Kong. Initially, China was only an interchange station on her journey, but in Shanghai and Xuzhou, where she witnessed tens of thousands of decomposing corpses, raped women, bloodied residents, and wounded soldiers resulting from the Japanese military actions, she became a volunteer nurse in a local hospital. In this process, she felt herself becoming a part of the Chinese citizenry. 
Rewi Alley, another New Zealand freelancer in China and the referee of Robin Hyde, was another good example. From 1927, he spent most of his life in China and devoted himself to the Chinese war of resistance against Japan as well as to primary education in China's rural areas. In 1982, he eventually became an ‘honorary Beijing citizen’. For Emily Hahn, the New Yorker's China correspondent, residing in Shanghai was not solely about journalistic work. She fell romantically in love with the Chinese publisher and Cambridge graduate Zau Sinmay (Shao Xunmei), despite the fact that Zau remained married to his Chinese wife. Both Hahn and Zau treated each other as family members, living together and co-publishing. The living conditions of many foreign correspondents and their entangled life trajectories with local people not only impelled them to speak for the Chinese in their publications but also re-shaped their own ways of living. As the American journalist Randall Gould maintained, 'For more than two decades I have lived mostly among the Chinese. Through this contact and by natural inclination, I am somewhat Chinese in my attitude toward life. ${ }^{31}$ However, these transnational identities and feelings are seldom captured by journalism historians, resulting in the lack of investigation into them.

The film industry also involves the transnational flows of individuals, which further entails the issue of transnational identities. Li Xianglan, also known then as Shirley Yamaguchi and Yoshiko Yamaguchi, was a singer and film actress familiar among Hollywood, Chinese, and Japanese entertainment circles in the twentieth century. Of Japanese descent, Li (Yamaguchi) was born in Mukden of China and was raised by her Chinese stepfather. In 1938, Li became a key figure in the Manchukuo Film Association - an institution aimed at facilitating Japan's cultural conquest of Asia. As she admitted in her biography, her Japanese and Chinese identities were intertwined throughout her entire life. Before the Second World War, she always treated 'Japan as her father country’ while seeing 'China as her mother country.' In high school, Li was educated by her stepfather to 'live as a Chinese woman'. However, when the zealous anti-Japan affections of the 1930s arose, Li chose to avoid being involved in any anti-Japan parades. In her own words: 'To get into Chinese society, I have to give up my identity as a Japanese subject. To be a Japanese, I was excluded by Chinese society. ${ }^{32}$ The Korean film actor Jin Yan was another example similar to Li Xianglan. After his relocation to China, Jin was cultivated as a Chinese actor. He won an award as the best Chinese film actor and was married to a Chinese film actress. On the one hand, he became Chinese and thus took an active part in the Chinese resistance against the Japanese invasion, while on the other hand, he maintained connections with Korean independence activists and secretly provided them with financial support. ${ }^{33}$ 
The transnational flow of professional managers is another intriguing topic. In the late nineteenth century, many media organisations in China were run by Western nationals, including the periodicals Shanghai Times (British), Peking and Tientsin Times (British), Shanghai Evening Post and Mercury (American), Le Journal de Shanghai (French), Deutsche Shanghai Zeitung (German), Shanghai Nippo (Japanese), the China Tribune (Japanese), Der Ostasiatische Lloyd (German), and L'Echo de Chine (French). During the twentieth century, the number of Westerner-run newspapers boomed. However, little research has treated the managing ranks (managers, chief editors, and property owners) of these media organisations as transnational journalistic professionals. ${ }^{34}$ Yet, before they commenced their professional careers in China, these managers already had successful experience as senior editors or journalists in Western countries.

Within the management team of the English-language newspaper the China Mail, the principal proprietor, George Murray Bain, was the former owner of a successful printing house in England. Its managing director, William Henry Donald, used to be the editor of the Daily Telegraph in Sydney and the Argus in Melbourne. While working for the China Mail, Donald was also a correspondent for the Daily Express in London. A. W. Brebner, the managing editor of the Hong Kong Telegraph, began his career in Scotland as a journalist for the Aberdeen Free Press before moving to Jamaica as a sub-editor for the Daily Gleaner. After a short-term appointment as correspondent for the Daily Telegraph, he became assistant editor for the Bangkok Times and the Straits Times in Singapore. In Shanghai, Henry Thurburn Montagne, the editor of the North China Herald, was an award-winning journalist working for the London Times. John D. Clark, the editor-in-chief of the Shanghai Mercury, was the founder of the Rising Sun in Japan. ${ }^{35}$ Unlike the 'Hankow Gang', many of whom moved to China to report on the war, these people in management positions moved to China to launch their newspaper businesses as transnational enterprises. For example, the American media professional F. P. Ball ran the Shanghai Times, which was established in 1901. Within the newsroom, most members of the editorial team were American nationals, while its marketing team was owned by a French company. In 1908, the newspaper began to receive a subsidy from Shanghai officials. Given this background, it remains unclear how (and to what extent) the transnational experiences of the newspaper's staff may have exerted influence on their changing journalistic beliefs.

The transnational flows of media personnel between Western countries and China occurred in both directions. While Western journalists and media professionals visited or worked 
in China, there were also many Chinese editors, reporters, and film performers working outside China. Some of them have already been mentioned in literature on media history, but others have not. Ng Poon Chew (1866-1931) is a familiar figure in books on American journalism history for his contribution to the founding of the first Chinese language newspaper in America, the Chung Sai Wat Po. While acting as its editor-in-chief, Chew was the deputy Chinese Consul General in Los Angeles and a leader of the opponents of the Chinese Exclusion Act. He was also known as 'China’s Mark Twain' as well as a person who was 'eminently qualified to lecture on the New China and her relation to the Western world' (Crittenden Record Press, 15 June 1916). However, there were many other Chinese media professionals working in America who are unfamiliar even to China scholars. For example, in 1905, the Los Angeles Herald approached and managed to secure the services of Tong Hing, then editor of the Hong Kong-based China Mail (Los Angeles Herald, 29 July 1905). Because of the bi-directional flow of media personnel, journalism became a transnational community of practice.

Historians have been aware of the friendship that existed between foreign journalists and Chinese officials such as Yuan Shikai and Hollington Kong Tong. ${ }^{36}$ However, the interpersonal relationships between Western correspondents and their Chinese counterparts have received little scrutiny. Li Sum Ling was an interpreter and translator for William Donald and his China Mail before joining Wah Tsz Yat Po (Chinese Mail) in 1908. Recommended by his Scottish-born American friend James Gordon Bennett, then the publisher of the New York Herald, Li was able to visit the headquarters of many American newspapers and was invited to deliver lectures on Chinese journalism in San Francisco, Missouri, Boston, and Chicago (Cf., Marion Daily Mirror, 10 October 1908; San Francisco Call, 29 October 1908). With the help of Bennett, a 'nobody’ of a Chinese newspaper became the 'prominent Chinese editor' (as he was described in the U.S. media outlets at the time). Yet, the relationships between foreign and Chinese news staff were not always harmonious. For example, R. I. Hope, the Indian writer for the China Republican and the Peking Daily News, was alleged to have had a rocky relationship with the Chinese proprietor of the Peking Gazette, Eugene Chen. ${ }^{37}$ To further investigate the transnational media agents and their networks, the interpersonal relationships between foreign journalists and their Chinese counterparts within newsrooms could be a meaningful topic, because it helps to reveal journalism as a transnational community of practice. 


\section{The transnational flows of journalistic content and education}

Transnational journalistic content refers to the migration of journalistic norms, genres, and texts across national borders and different cultures. Two theoretical frameworks are pertinent to understanding this process. One is the 'traveling theory' proposed by Edward Said, ${ }^{38}$ which holds that when a concept or theory travels from one cultural context to another, its meaning might not remain consistent. In this light, historical contingency is likely to frame the interpretation and use of a certain concept, theory, genre, or discourse. This proposition is widely supported by works in the research areas of discourse studies, ${ }^{39}$ conceptual history, ${ }^{40}$ and translation studies. ${ }^{41}$ The other theory is postcolonialism, and especially the theory of ‘cultural hybridity', which emphasises the dynamic and mutual affections between cultural subjects. In this light, while outsiders change local landscapes, they, in turn, are changed by the locals. ${ }^{42}$

Historians have found that Chinese cultural traditions exerted enormous influence on the modality and application of foreign-style Chinese-language newspapers in late nineteenth-century China. ${ }^{43}$ For example, the missionary editors of the world's first Chinese-language periodical, the Chinese Monthly Magazine, adapted its foreign style to the Chinese context by adding many traditional Chinese elements to the cover-page layout. In terms of publication dates, the Chinese lunar calendar was adopted in place of the Gregorian calendar. They also included a Confucian saying in the masthead. In early twentieth-century China, even the many newspapers that adopted the Gregorian calendar continued to use the lunar calendar to indicate the publication date. Similar instances were not restricted to print journalism. In the 1920s, the Japanese colonisers firmly controlled the film industries of the Korean Peninsula and implemented censorship on Korean movies. Many Korean film directors, photographers, and performers were forced to move to Shanghai, where they continued producing Korean-language films reflecting their thoughts of national independence and antiimperialism. However, only a few years after their relocation, the Korean film workers were gradually influenced by their Chinese counterparts and became interested in producing romantic love stories and martial arts films, with their messages of national independence and anti-imperialism no longer featuring. ${ }^{44}$

Perhaps a more complicated issue is the transference and appropriation of journalistic concepts and norms. From the nineteenth century onwards, many Western journalistic concepts 
and norms became familiar in China, including freedom of the press, the fourth estate, journalist, editor, newspapers, objectivity, news, and feminist journalism. This trans-cultural transference of concepts was facilitated by the translation of key texts into Chinese. In many cases, the Chinese translation was based on a Japanese translation of articles originally written in Dutch or Portuguese. Due to the complications in multilingual translation, the meanings and connotations of concepts and norms may have differed in their Chinese context as compared to their original, Western contexts. For example, when the Western concept of press freedom was introduced to China in the nineteenth century, the majority of Chinese intellectuals filtered out or ignored the libertarian and theological discourses surrounding the concept, thus regarding press freedom simply as an instrument to strengthen the country. This was far from being identical with its interpretation in the West. ${ }^{45}$ Another example is the Western concept of the fourth estate. This originally meant the right of journalists to report on the House of Commons from within parliament, but when the Japanese scholar Matsumoto Kunpei introduced the concept to Japan in 1899, he confused the right of journalists with the power of journalists and thus translated the term 'fourth estate' as 'fourth race' - defining journalists as the most powerful people against nobles, monks, and commoners. On the basis of Kunpei's translation, Chinese intellectuals further interpreted journalists as the fourth race and being 'the supreme power in every aspect of social life'. ${ }^{46}$

Before international news agencies such as Reuters and the Associated Press established information services in China in the late nineteenth century, the transnational flows of news content between the West and China had relied significantly on the translation of news that had originally been reported and printed in local newspapers. While a major portion of the content in Chinese newspapers was taken up by translated news articles originally published in Western periodicals, Chinese newspapers were still seen by the Western world as a significant source for understanding East Asia. For newspapers published in Singapore, the United States, the United Kingdom, Sweden, Australia, and New Zealand, news about China matters was mainly sourced from the Peking Gazette, North-China Herald, and Wah Tsz Yat Po. Since the Peking Gazette was the only official newspaper in imperial China dedicated to publishing government news, Western politicians saw it as an important source of intelligence. Therefore, translating content from the Peking Gazette became a profitable business. In the nineteenth century, for example, the East India Company 
engaged missionaries to translate the Peking Gazette into English, which they then sold to British politicians and media organisations, including the London Times. Australian newspapers saw the Peking Gazette as 'a reflection of the national mind [of the Chinese]' (Gippsland Times, 2 November 1877). From the 1840 s onwards, Australian newspapers such as the Australian, the Cornwall Chronicle, the South Australian, and the Sydney Morning Herald filled their columns on Chinese affairs with translated news items originally published in the Peking Gazette. At the same time, for China's part, the imperial government saw these translation businesses as a form of espionage. The Chinese emperor ordered local governors to arrest Chinese people who were involved, but the Western translators were still able to obtain copies of the Gazette by virtue of their private networks in China.

Journalism education in twentieth-century China was also transnational in nature, which is exemplified by the Missourian journalism education in the republican era. In recent years, Chinese scholarship has shown that most of Chinese institutions of journalism education in republican China were founded by graduates of the Missouri School of Journalism in the United States. ${ }^{47}$ Amongst these institutions, the Department of Journalism at Yenching University was more like an overseas campus of Missouri, sharing the same teaching faculty and textbooks. The department was also a member institution of the American Association of Schools and Departments of Journalism at the time. However, the so-called 'Missouri Mafia' only successfully imported Missourian pedagogy and the organisational structure of journalism education institutions to China, rather than their journalistic ideals and norms. As pragmatists, in their everyday teaching, the Chinese Missouri graduates placed greater emphasis on the practical aspects of journalism but failed to integrate Western liberal thought into their classes. ${ }^{48}$ This pragmatic practice in the aspect of journalism education also echoed the adaption and appropriation of journalistic content in the transnational history of journalism. It acted as a vivid example of transcultural knowledge transfers.

\section{Final remarks}

While existing literature on transnational journalism histories mainly focuses on journalistic exchanges between countries within the Euro-American world, this article shows that Chinese 
scholarship and China matters were also involved in transnational journalism histories. The transnational flows of journalistic agents, networks, content, and education mentioned in this article are fundamental for understanding the entanglements between the media landscapes of China and those of other cultures. However, discussions of this kind, as Cronqvist and Hilgert argue, have been 'in the shadow of [European] scholarly interest' and have undergone limited examination. ${ }^{49}$

This may result from the two main difficulties confronting Western journalism historians seeking to research this context: the language barrier and limited access to Chinese archival materials. It is impractical for historians to visit multiple archives in person in order to obtain the historical sources of the country they are researching. The current difficulties resulting from the COVID-19 pandemic have made cross-border travel even harder. However, tools of digital humanities such as electronic databases could be utilised to overcome these challenges. Alongside the various online databases developed by ProQuest and the international publisher Brill, with which Western historians are already familiar, the newly developed database of Chinese Historical Documents (Zhongguo lishi wenxian zongku) and the Platform of the Anti-Japanese War and Modern Sino-Japanese Relations (kangzhan wenxian shuju pingtai) are also appealing to researchers dealing with transnational journalism histories. By de-emphasising the nation-state as the unit of analysis, the transnational approach to journalism history encourages historians to reach out beyond national borders and develop collaborative research partnerships that make best use of the resources, expertise, and language skills of scholars working in diverse parts of the world. In doing so, language barriers may no longer be a serious issue for media historians working on transnational projects.

\section{Notes}

1. Cf. Bridget Griffen-Foley, “Inaugural KS Inglis Address: Making Australian Media History,” Media International Australia 170, no.1 (2019): 3-21; Marie Cronqvist and Christoph Hilgert, "Entangled Media Histories: The Value of Transnational and Transmedial Approaches in Media Historiography,” Media History 23, no.1(2017): 130-141; Michele Hilmes, “Entangled Media Histories: A Response,” Media History 23, no.1 (2017): 142-144; Andreas Fickers and Catherine Johnson, “Transnational Television History: A Comparative 
Approach,” Media History 16, no. 1 (2010): 1-11; Debra Reddin van Tuyll, “Journalism History without Borders: The Transnational Paradigm and the Case of John Mitchel," American Journalism 34, no.1 (2017): 91-102. For the convenience of writing, I use the term 'transnational journalism history' in this article.

2. Bridget Griffen-Foley, “Entangled Media Histories: A Response,” Media History 23, no. 1 (2017): 145-147.

3. Cronqvist and Hilgert, "Entangled Media Histories."

4. See Akira Iriye, Global and Transnational History: The Past, Present, and Future (New York: Palgrave Pivot, 2013), 3; Thomas Adam, “Transnational History,” in Yearbook of Transnational History, edited by Thomas Adam (Vancouver: Fairleigh Dickinson University Press, 2018), 1-10.

5. Cf. Thomas Bender, Rethinking American History in a Global Age (Berkeley: University of California Press, 2002); Niall Whelehan, Transnational Perspective on Modern Irish History (New York: Routledge, 2015); Ian Tyrrell, The Gaderns of the Gods: Californian-Australian Environmental Reform, 1860-1930 (Berkeley: University of California Press, 1999).

6. Iriye, Global and Transnational History.

7. Pierre-Yves Saunier, Transnational History (New York: Palgrave Macmillan, 2013).

8. Marcel Broersma, "Transnational Journalism History: Balancing Global Universals and National Peculiarities," Mediem \& Zeit 25, no.4 (2010): 10-15.

9. Broersma, "Transnational Journalism History."

10. Michael Werner and Bénédicte Zimmermann, “Beyond Comparison: Historie Croisée and the Challenge of Reflexivity," History and Theory 45, (2016): 30-50.

11. Cronqvist and Hilgert, "Entangled Media Histories."

12. J. D. Burson, "Entangled History and the Scholarly Concept of Enlightenment." Contributions to the History of Concepts 8, no.2 (2013): 1-24.

13. See Fickers and Johnson, "Transnational Television History."

14. Van Tuyll, “Journalism History without Borders," 91-102.

15. Hilmes, "Entangled Media Histories."

16. Sebastian Conrad, What Is Global History (Princeton: Princeton University Press, 2016), 44-45.

17. Cf. Frank Dikötter, The Age of Openness (Hong Kong: Hong Kong University Press, 2008); Bruce A. Elleman, International Competition in China, 1899-1911 (London: Routledge, 2015); M.R. Godley, “China’s Policy Towards Migrants, 1842-1949," in Asians in Australia: The Dynamics of Migration and Settlement, edited by C. Inglis (Singapore: Institute of Southeast Asian Studies, 1992), 1-21. 
18. For example, in her memoir published after returning to America, the prominent China war reporter Agnes Smedley felt that she was in nature not American but Chinese. This feeling was shared amongst her fellow Anglo-American journalists during the inter-war years. Other examples, such as Robin Hyde and Zau Sinmay, have been provided in later paragraphs of this article.

19. See Christopher Reed, Gutenberg in Shanghai: Chinese Print Capitalism, 1876-1937 (Vancouver: UBS Press, 2004); Also see Xiantao Zhang, The Origins of the Modern Chinese Press: The Influence of the Protestant Missionaries (London: Routledge, 2007).

20. Paul W. Harris, “Cultural Imperialism and American Protestant Missionaries: Collaboration and Dependency in Mid-nineteenth-century China," Pacific Historical Review 60, no.3 (1991): 309-338.

21. See, Robert Eric Frykenberg, Christians and Missionaries in India (London: Routledge, 2013).

22. See, Bible Society Record, “The History of Bible Translation into the Japanese Language," Bible Society Record 56, no.11 (1911): 177-180.

23. Kathleen L. Lodwick, The Chinese Recoder Index (Wilmington: Scholarly Resources Inc., 1986), xi.

24. For example, Paul French, Through the Looking Glass: China's Foreign Journalists from Opium Wars to Mao (Hong Kong: Hong Kong University Press, 2009); Stephen R. MacKinnon, Reporting China: An Oral History of American Journalists in the 1930s and 1940s (Berkeley: University of California Press, 1987); Mordechai Rozanski, The Role of American Journalists in Chinese-American Relations, 1900-1925 (Unpublished Doctoral Dissertation). University of Pennsylvania, Philadelphia, PA, 1974.

25. See, for example, Paul French, Carl Crow: A Tough Old China Hand (Hong Kong: Hong Kong University Press, 2006); Yi Guo, “New China or New America: the American Media Myth of 'New China', 1911-1913," Media History 25, no.2 (2019): 145-162.

26. MacKinnon, Reporting China, 37-47.

27. Ibid., 38-40.

28. Robin Hyde, China Rampant (London: Hurst and Blackett, 1938).

29. Relevant archives can be found at the Chongqing Archive in China. For example, file numbers 0004-000100088-0000025 and 0004-0001-00088-0000074.

30. Relevant documents can be accessed at the Chongqing Archive. File numbers 0053-0013-00018-0000-065000 and 0053-0025-00004-0000-040-000.

31. Randall Gould, China in the Sun (New York: Doubleday, 1946). 
32. Cited in Hou Jie and Liu Yichen, "Riben qinhua zhanzheng shiqi nümingxing de xingxiang jiangou” [Image Constitution of Female Stars during the Japanese War of Aggression against China], Anhui shixue [Historical Research in Anhui] 39, no.1 (2018): 88-96.

33. Xu Zhen, Zhongguo yu chaoxian bandao dianying jiaoliu shi yanjiu (1896-1953) [Study on Historical Exchange of Cinema between China and the Korean Peninsula] (Unpublished Doctoral Dissertation), Northeast China Normal University, Changchun, China, 2017.

34. Amongst the very limited works, Peter O'Connor's research should be noted. See Peter O'Connor, The English-Language Press Networks of East Asia, 1918-1945 (Kent: Global Oriental, 2010).

35. W. H. Donald, "The Press," in Twentieth Century Impressions of Hong Kong, Shanghai, and Other Treaty Ports of China, edited by A. Wright (London: Lloyd’s Greater Britain Publishing, 1908), 343-367.

36. See French, Through the Looking Glass. Also see Shuge Wei, News under Fire: China's Propaganda against Japan in the English-Language Press, 1928-1941 (Hong Kong: Hong Kong University Press, 2017).

37. Hollington K. Tong, Dateline: China, the Beginning of China's Press Relations with the World (New York: Rockport Press, 1950), 9.

38. Edward Said, The World, the Text, and the Critic (Cambridge, MA: Harvard University Press, 1983), 226-247.

39. T. A. van Dijk, Discourse and Power (New York: Palgrave Macmillan, 2008).

40. Cf. Quentin Skinner, "Meaning and Understanding in the History of Ideas," History and Theory 8, no.1 (1969): 3-53; Reinhart Koselleck, Future Past: On the Semantics of Historical Time (Cambridge: MIT Press, 1985).

41. Lydia H. Liu, Translingual Practice: Literature, National Culture, and Translated Modernity - China, 19001937 (Stanford: Stanford University Press, 1995).

42. Cf. Robert F.C. Young, Colonial Desire: Hybridity in Theory, Culture and Race (London: Routledge, 1995); Peter Burke, Cultural Hybridity (Cambridge: Polity Press, 2009); Homi Bhaba, The Location of Culture (New York: Routledge, 1994).

43. See, for example, Joan Judge, Print and Politics (Stanford: Stanford University Press, 1996); Barbara Mittler, A Newspaper for China. Cambridge (MA: Harvard University Press, 2004).

44. Xu, Zhongguo yu chaoxian bandao dianying jiaoliu shi yanjiu (1896-1953).

45. Yi Guo, Freedom of the Press in China: A Conceptual History, 1831-1949 (Amsterdam: Amsterdam University Press, 2020).

46. Yi Guo, "The Liminal Landscape: The Reception of Western Press Freedom in Late Imperial China," Javnost - The Public 26, no.1 (2019): 17-32. 
47. See, for example, Zhang Wei, "Misuli xinwen bang yu zhongguo" [Pro-China Journalists in Missouri School of Journalism], Guoji xinwen jie [Chinese Journal of Journalism and Communication], no.10 (2018): 76-80.

48. Guo Jing, "Fangfa yizhi yu linian liushi: misuli bang de xinwen jiaoyu huodong kaocha” [Missouri Mafia and Journalism Education in China], Xinwenjie [Journalism and Mass Communication Monthly], no. 8 (2018): 68-77.

49. Cronqvist and Hilgert, "Entangled Media Histories."

\section{Biography}

Yi Guo, PhD (Macquarie University), is an Associate Professor of Media and History in the School of Journalism at Chongqing University in China. He is also an honorary member of the Centre for Media History at Macquarie University. Yi is the author of Freedom of the Press in China: A Conceptual History, 1831-1949 (Amsterdam University Press, 2020). He has also published in English-language journals such as Javnost - The Public and Media History.

\section{TMG Journal for Media History}

Volume 24 No $(1 / 2) / 2021$

DOI

https://dx.doi.org/10.18146/tmg.781

PUBLISHER

Netherlands Institute for Sound and Vision

\section{COPYRIGHT}

Each article is copyrighted (c by its author(s) and is published under license from the author(s). When a paper is accepted for publication, authors will be requested to agree with the Creative Commons Attribution 4.0 International License. 